\title{
Marketing and Campaign Management via Social Networks and the Effects of Electronic Advertising \\ Foued Sabbagh
}

\begin{abstract}
This paper aims to show that the marketing and management of advertising campaigns have contributed in a positive and growing way since the nineties until now bring in targeted customers and increase sales of electronic products. Social communication networks are transformed into the promoting and marketing advertising forum in order to automatically attract customers without the need for traditional sales methods. In this sense, electronic marketing represents the space of commercial transactions of the future. Therefore, this type of marketing and the management of campaigns promoting social media via social networks have a direct impact on internet users by the effect of electronic advertising.
\end{abstract}

Keywords: Electronic Marketing, Social Media, Campaign Management, Promotion, Electronic Advertising.

\section{INTRODUCTION}

The marketing through networks of social communication from the management of the advertising campaigns of a specific product is more important operations to attract and gain visitors for your electronic site or clients for your services or promotion to sell your product or sale of electronic products by paying commission. Bampo M, Ewing M.Y, Mather D.R, Stewart D and Wallace M (2008) [1], deconstruct the viral marketing process into the following components; underlying population and their social connectivity, the campaign characteristics, the behavioral characteristics of the audience that facilitates the propagation of the message, the size and connectivity of the successfully reached audience, and measures of dynamic campaign progress. Specifically, this study deconstruct the size and connectivity of the population as a network, taking into account the campaign characteristics also then simulate the campaign, and the campaign performance measures are reflected as properties of the stimulation. The sites of social communication have given in a positive direction during the last decade in the operations of marketing and publicity, and the sale of electronic products through the creation of content attracts the attention of readers and promotes them to participate in nets of social communication.

\footnotetext{
Manuscript received on 08 May 2021 | Revised Manuscript received on 25 May 2021 | Manuscript Accepted on 15 June 2021 | Manuscript published on 30 June 2021. * Correspondence Author

Foued Sabbagh*, Finance and Development, Faculty of Law and Economics and Politics Sciences/University of Sousse, Erriadh City, Tunisia. Email: fouedsabbagh_2010@yahoo.fr

(c) The Authors. Published by Lattice Science Publication (LSP). This is an open access article under the CC-BY-NC-ND license (http://creativecommons.org/licenses/by-nc-nd/4.0/)
}

The electronic commerce presents the real revolution in the area of distribution and sale of products of global companies on the net. The networks of social communication are processed at the forum proponent and advertising in marketing in order to attract the customers of automatic manner without the need for marketing and promotion and of a traditional sale. The social media has become the method of statement in the 21 century, enabling us to express our belief, ideas and manner in an absolute new way (Saravanakumar M and Sugantha Laskshmi T (2012)) [21]. The marketing through networks of social communication is one of the ways the most recently embraced and the most active in the operations of marketing and promotion electronic and which allow companies or persons proponents of access absolute easily to millions of people by day. This type of management of the campaigns is considered the most effective by modern means of marketing with the surveillance and monitoring of the behaviors and desires of customers and users and consumers. Thus, through listening to their concerns and to discuss their needs and to determine their wishes and provide a product for their interests. The information that travels through networks of social communication have provided the main base of companies and developers who are building the management of campaigns through the fixing of the objective in the interest of each category given to the particular area. The evolution of this method with the beginning of the emergence of the internet, the networks of social communication and of current wide, including the new technologies of communication, which has caused a real revolution in the field of marketing and promotion, and the sale of electronic products. The world has become a small village and millions of people and global corporations in permanent contact with one another. Subsequently the promoters and the companies are capitalized of this electronic space to enable networks of social communication of platforms for the promotion, commercial stores and advertising space in order to attract the largest possible number of their customers and to influence their buying products to promote electronic. If it has been exploited these networks of exploitation broad because they exemplify the ways in which power from increase the sale and to attract customers and to communicate with them and to work on them. This method of modern marketing represents the best modern means to sell and promotion by commission, customers are become as they could exchange views on the products or the services that incite to the internet and the networks of social communication, is also becoming capable of assessment, comment and of admiration and make their views known and to criticize or the electronic products. purchase of

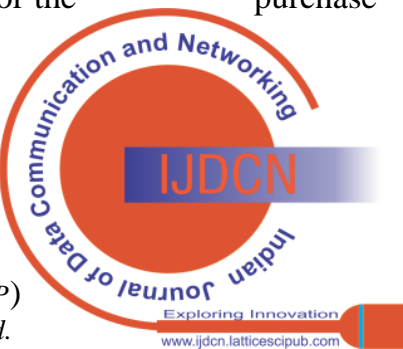


The electronic marketing represents the trade of the future, in particular in the developed nations and the countries of the Gulf to find many clients and purchasers whose financial means to purchase through the substance of social communication, but this case of marketing remains limited in poor and developing nations. The selling and the management of campaigns for the forwarding of the means of social communication have a considerable impact on the attract customers and to be speak for the leverage of electronic products, in particular with certain categories of some States are available for all the opportunities and means. In addition, the electronic shops are the main types of modern trade occurred in the contemporary world, where are occurring daily millions of procurement operations and financial transactions by internet. What we intend to networks of social communication? And how the process of marketing and management of promotion campaigns are done through the means of social communication? And what is the impact of the announcement in the social networks on the desires and interests of consumers?

\section{THE NETWORKS OF SOCIAL COMMUNICATION}

Traditionally, social network models have been descriptive, rather than predictive; they are built at a very coarse level, typically with only a few global promoters, and are not useful for making actual predictions of the future behavior of the network (Domingos P (2005)) [6]. In the past, this was largely due to lack of data; the networks available for experimental study were small and few, and contained only minimal information about each node. Fortunately, the rise of the internet has changed this dramatically. For the management of marketing campaigns and promotion of products through networks of social communication, it must have a good speed of internet access, because the communication with the customers requires a quality of digital communication and an organization govern the promotion of products and the circulation of information marketing. The factor of the maximum speed of communication on the internet is considered to be as more important factor in the organization and the operation of the main database of information. The factor web design and the character of the site and image is contributes to attract purchasers and customers and to contribute to the strengthening of the trust on the site and the purchase request, in particular in European and American societies and the states of the Gulf. Fig.1. Among the more important platforms of social communication have noted the sites of social communication and mobile phone.

\section{A. The Sites Networks of Social Communication}

Recent years have witnessed the rise of new media such as Facebook, Youtube, Google+ and Twitter, which enable customers to take a more active role as market players and reach and be reached by almost everyone anywhere and anytime (Hennig-Thuran T, Malthouse F.C, Friege C, Gensler S, Lobschat L, Rangaswamy A and Skiera B (2010)) [8]. Where these sites allowing connection with millions of people in the world and a direct and very fast. These communications contribute to the promotion of products with the implementation of a process of participation or re-tweet to customers on the publications, which poses the marketer if the customer is interested by the publication asked in marketing. The study of Hennig-Thuran T, Malthouse F.C, Friege C, Gensler S, Lobschat L, Rangaswamy A and Skiera B (2010) [8]. introduces a new "pinball" framework of new media's impact on relationships with customers and identifies key new media phenomena, which companies should take into account when managing their relationships with customers in the new media universe. In addition, for these sites allow publishing electronic messages and commercial information which wants the marketer has sent in a broadly spectacular and at a broader level in a very short period and without a lesser difficulty if the use of these sites has been correctly. The sites of social communication contain a vast amount of information on the services or products that could target customers to dissect the market and to meet the required products in conformity with their interests and their desires. The networks of social communication on the internet consider the best way of social communication in order to facilitate the process of creation of commercial stores and trade promotion campaigns to millions of global products, also allows the exchange of information and content through the images and videos and other files between different promoters, the clients and the companies electronically. The networks of social communication constitute points of convergence continues and related of type of social links which lead to the circulation of information in a way that enormous between millions of masses at very short delay, then that these publications have directly affected the targeted clients. The users are different on each platform (Blank G and Lutz C (2017)) [4]. The Facebook use is influenced by age and gender, but not income and education. LinkedIn adoption is affected by income, but not age, gender and education. For Twitter, age and income but not gender and education mater. These sites allow surfers of the internet the creation of lasting relationships and to transform the world to a small village with the exception of the means of publication and participation and the creation of commercial stores and the circulation of information in less than a minute between millions of people. The spread of the internet and the increase in the number of users of the creation of many networks, social virtual constitute a commercial space, entertainment, of friendship and correspondence between and the sale and purchase of electronic products. The most known of networks of social communication currently existing we note:

\section{- Facebook:}

One of the most major sites of networks of social communication on the one hand, from the speed of the proliferation and the expansion of this which contains enormous quantities of information stored in which and the ease of use and trade and the promoter of the products.

The number of its employees in the course of these last year's exceeds one billion users in the world because of renown, and considerable use which fostered by this site social. The title signed on the internet is: (www.facebook.com), put in place the first version of this site in social February 2004 according to the student in a specialty of the media in the American University Harvard Mark Zukelberg to the age of the time not more than twenty years.

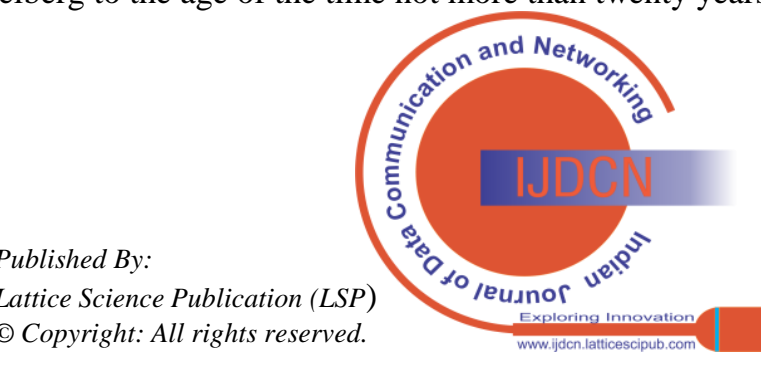


Facebook users can create profiles featuring personal information, interests, photos, and the like, and can friend other site users (Smith A.N, Fischer E and Yongjian C (2012)) [23]. The site is reserved to students of the university and then small group, and then it is between the world of trade and the universal promotion at the start of September 2006. It has exceeded the number of users of this site of the year 2012 a billion of the users, and this figure are still growing. In addition, this site allows the creation of commercial stores, groups of friendship, commerce and promotion, forums, and allows you to publish images and videos and of opinion polls of observations through the comments, I like it and then add to the personal page. The social media values a prominent marketing strategy Facebook (FB) to influence receiver's attitude and share messages with others (Chen L.Y and Fang C.Y (2017)) [5]. In this reason, Saravanakumar $M$ and Sugantha Laskshmi T (2012) confirm the using Facebook to capture customers. Here are five ways they are connecting with customers on Facebook such as promotions, crowd sourcing, check-ins, games, social shopping. Businesses on Facebook can really benefit from the trusted referrals of their friends, which is something missing from the monologue of advertising (Janusz T (2009) [12]. This site contributes to deploy the largest number of participants to identify the products of companies in the world and the publication of the electronic advertisements on the page of the site and the movement between millions of target clients.

\section{- Twitter:}

The site Twitter is the largest second network social continues after the Facebook, the title of his internet site is (www.twitter.com). This network was officially created on 21 March 2006 by Mr. Jacques Dersay and launched in the month of July of the same year an official site of social communication. The number of network users is more than 500 million subscribers in the year 2012 and it is constantly increasing and accelerated. It would also allow this network to the tweeter on its site and promote all products faster to Facebook in order qua the communication of more than a billion people for a single tweet and a second. In addition, you can use a software to make this site as a global forum for the publication of information and electronic products among all target groups in a manner of high quality. Twitter is a micro-blogging site is a form of blogging (Saravanakumar M and Sugantha Laskshmi T(2012); Smith A.N, Fischer E and Yongjian C (2012); Jansen B.J, Zhang M, Sobel K and Chowdury A (2009)). This network allows for the exchange of messages to short duration not exceeding 140 characters and this network is used in a way of messages on the mobile phone, the computer and the TV intelligently. Twitter can also be used to announce offers or events, promote new blog posts, or keep the readers in the know with links to important news stories (Saravanakumar M and Sugantha Laskshmi T (2012)). In addition, given the ease of monitoring any brand's sentiment, one can view microblogging as a competitive intelligence source (Jansen B.J, Zhang $\mathrm{M}$, Sobel $\mathrm{K}$ and Chowdury A (2009)). The Tweet on Twitter allows you to this social network to their service users of the blogging and the electronic advertising. It is necessary to check the Tweet proponent, where it has been established all tweets or all other tweets for the return of the people to your site promotion. The site Twitter is a commercial space to bring together the promoters, global corporations and the targeted customers.

\section{- YouTube:}

YouTube is the first site of advertising with the videos on the internet entitled (www.youtube.com). This site was created in February 2005 in The United States of America then it was sold on the website of the company Google, and the number of users of the site exceeds 800 million users in 2012. Youtube is content community; it allows users to post, view, comment on and link to videos on the site (Smith A.N, Fischer E and Yongjian C (2012)) [23]. Users can also set up personal profiles that display who they subscribe to, recent activity, friends, comments and favorite videos. This site is dedicated primarily to publish and share videos. Hence, this website permits users to download or to publish or comment on pictures. Also, a firm that capitalizes on the digitalization of video contents by managing major Youtubers and connecting them with advertisers (Griborn E and Nylén D (2017)) [7]. Online video can be said to challenge some of the hierarchical structures associated with the broadcast TV industry, as anyone with a smartphone and an internet connection can produce content and publish it on online video platforms and networks such as Youtube. We could create a commercial page or special promotions for traders and the proponent's electronic or global corporations who wish to by attracting the greatest possible number of its customers. This site is made up the site more active so that it is loaded each of the thousands of the sequences of the videos and the movement between millions of people. We can make a publication of advertising on this site and the exploitation videos for the promotion and the direct advertising of the products desired by customers.

\section{- LinkedIn:}

The LinkedIn network is considered the most important networks of social communications professional, created in 2003 in the United States of America, the title of the web site is (www.linkedin.com), also this network represents a commercial area and matters of professional marketing, and the number of subscribers is 150 million subscribers at the beginning of the year 2012. This network specializes in the field of business and they allow users to communicate between the various officials of the special institutions, in particular the frameworks of the institutions. McCabe M.B (2017) [18], addresses social media marketing strategies relating to career advancement and focuses mainly on LinkedIn. It is mostly a descriptive this site, summarizing the main arguments in favor of social media as a useful tool of job search and career advancement. Recent job seekers are more sophisticated as to whom they search for as employers. Social media and analytics now connect job candidates with career opportunities. The employers seek candidates through social media has caused disruption of traditional recruitment.

\section{- MySpace:}

Is the site that it was the most famous and popular before Facebook, this social network in generously hosted in 2003 in the United States of America, the title of the web site is (www.myspace.com). This network contains many advantages that enable proponent's connections with customers and their product necessary.

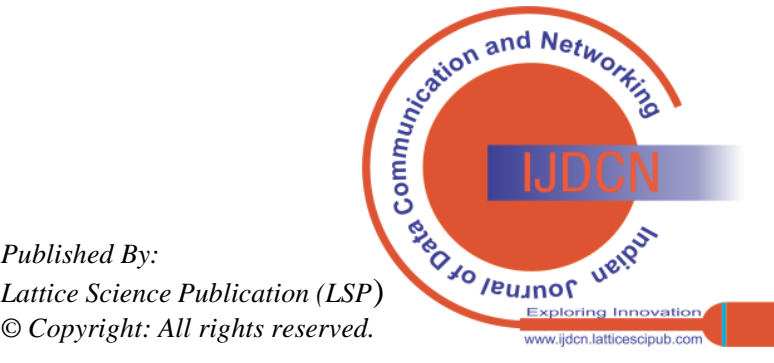


MySpace initially appealed to teenagers, but now half of the visitors to the site are age 35 or older as the site's demographic composition centimes to shift (Janusz T (2009)) [11]. This site to registered users access to obtain free spaces to the internet that allow them to develop personal information on themselves, with the creation of web sites, particularly for the participants and to transform them into the shapes of marketing a product. In addition, you can use the E-mail of this social site.

\section{- Google +:}

This social network is characterized with many benefits also located on the Facebook network. This page is launched on 21 June 2011 in the United States of America. This site is also characterized by the possibility to integrate the page of marketing with a number of Google services such as Google Adwords and Google Maps but even YouTube. This social network provides the same services that provided by the Facebook network with more details on commercial information and products and services. There are some previous examples of Google+ being integrated as a blended learning platform for higher education (Steino $\mathrm{N}$ and Khalid M.S (2017)) [24]. The students perceive Google+ as a social networking platform, which is more formal than Facebook, and experience more of creative freedom with Google+ than with Moodle. A side of these social sites the most popular and the movement between the users, we find the other group of the means of social communication and who considered the more popular with groups of the friendship and the correspondence and less use for the proponents and the electronic traders. We note the site Badoo (www.badoo.com), the site Pinterest (www.pinterest.com), the site Tumblr (www.tumblr.com). The site Instagram (www.instagram.com), the site of the videos, Dailymotion (www.dailymotion.com), the site Fliker (www.fliker.com). These sites allow publishing the videos and the movement of short messages and images and comments. In general, the services of these networks are concentrated for the categories which seek knowledge and recreation and to maintain their exploitation in the field of electronic commerce has remained limited.

\section{B. The Mobile Phone Applications}

The mobile phone applications (apps) are intelligent the final average of marketing and promotion through the means of social communication audio and written and visual. These applications have generated substantial interest among marketers, primarily because of their high level of user engagement and the positive impact this presumably has on a user's attitude toward the sponsoring brand (Bellman S, Potter R.F, Treleaven-Hassard S, Robinson J.

A and Varan D (2011)) [2]. This study confirms that using branded mobile apps has a positive persuasive impact, increasing interest in the brand and the brand's product category. Branded apps have a large effect on the favorability of brand attitude, but only a small effect on purchase intention. In addition, a way to continue directly with customers for the promotion of products and to persuade them of the quality of services and products for sale also in recent years is transformed one of the key elements of marketing and promotion of the largest corporations in electronic commerce and direct sales in the world who enjoys popular among users of all sectors and all age groups. The mobile phone is transformed to a working instrument introduced the direct sale and communication with customers, including knowledge "Telesales", and offer of availability or characteristics of social networks through the publication and the comment and the sending of short messages. The mobile marketing offers direct communication with customers, anytime and anywhere (Scharl A, Dickinger A and Murphy J (2005)) [22]. It is therefore informed the user of a completely new publication or a new product is placed on the markets for sales on the sites of social networks and directly by mobile phone. The mobile phone applications are easily accessible to the customer referred by its concerns and wishes to provide ongoing the last recent developments on the product or service that he wanted to and marketing or direct sale connection with him. The trade and distribution of products by applications of smart phones are considered the modern marketing operation depend on the largest global companies. There are many applications of mobile phones, intelligent and provide communication services, free and send short messages also free to communicate with social networks by audio and video, we note the more important, Viber, WhatsApp, Skype, Messenger, Tango. Also, many other applications which are less used by consumers of these free applications.

\section{THE MARKETING AND MANAGEMENT OF THE CAMPAIGNS THROUGH NETWORKS OF SOCIAL COMMUNICATION}

During these last years the networks of social communication have become a space of marketing and promotion of the products. Has also been used these networks for the purposes of marketing and commercial, of the study and the analysis of the behavior of consumers, the search of the target clientele and ensure their product according to their needs and their personal desires and to measure the degree of satisfaction of clients, the advertising and the electronic advertisement on the pages of the networks of social communication, monitoring the comments and concerns and suggestions from clients who are looking for electronic products.

The impact of e-viral marketing campaign can be influenced by the message attractiveness, the campaign design, and my intervention strategies (Bampo M, Ewing M.T, Mather D.R, Stewart D and Wallace M (2008)). The attractiveness or perceived value of a viral message as well as offering an incentive, if any play an important role in determining a recipient's propensity to forward the communication as well as which communication links to activate from within their digital network connections. In addition, taking into account the increase more and more users of these networks, the global corporations and the proponents of electronic products are exploited these modern techniques in the field of the management of the business by the social communication, by following these networks are transformed to a database of marketing and a management of campaigns in order to attract more possible number of clients and persuade them to marketing of services and the quality of the products by electronic means.

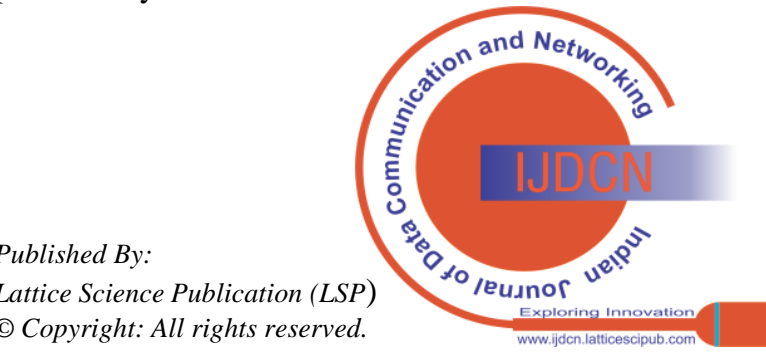


Now to the possibility of global companies or developers to attract consumers of networks of social communication and convince them to purchases or monitoring of services on their own sites while encouraging visitors to the site of the registration and the integration of the services of the society and the discussion on how to improve the services and to promote the products electronically. The brand equity is regarded as a very important concept in business practice as well as in academic research because marketers can gain competitive advantage through successful bands (Lassar W, Mittal B and Sharma A (1995)) [15]. Given the interest that this type to promote through networks of social communication electronic marketing has become a basic element in the management of marketing campaigns on these networks. The electronic commerce has become a prestigious status on the internet because of the profits and the considerable gains that provide this sector in the daily operations of sale and purchase and transfers electronic financial important. Where, the most important methods of marketing and management of the campaigns through networks of social communication we note:

- The establishment of excellent relations with clients and to offer the possibility to integrate with the special sites of corporations or promoters with the follow-up of their comments, their interests and their applications.

- The use of new techniques in the field of modern communication technologies, as the new systems of computing, the smart phones, iPad devices and other devices related to the internet of top quality in direct contact with a considerable speed.

- The conversation and interaction through the publication of the information and communication with the clients by the voice and the image.

- The influence on the clients in the way of persuasion and the attraction to buy.

- Identifying the products of sponsor him and the place or the State and the age group and of the tranche interested in this type of products.

- Identification the daily budget and duration of marketing campaigns on the networks of social communication.

- Selection some sites of social communication and of the global software to strengthen the management of promotional campaigns.

- Send messages to the campaigns by various means of modern communication on networks of social communication.

- The interest with the participation of clients through the comments or requests for products desirable.

- The increase in sales and subscriptions to customers in the sites of global companies.

The return to the supplement to the promotion on the means of social communication through the services of reference in social, attract visitors to the sites of social communication, and advertisements, the software for the automation of marketing, the publication of the advertisements on the Facebook groups, the creation of commercial stores on the means of social communication, promote the products through the means of social communication, research and the timing of the content not limited of the means of social communication, the management of advertising campaigns paid in advance on the means of social communication in order to improve the quality of the promotion and sales. In general, it is considered that the modern media based on the interaction of users such as social networks are involved in the increase in the demand for electronic products and the opening of the important links with the various sectors to hear their wishes and their applications in several areas and in the course of the advertising and the electronic advertisement and direct marketing of products. Thus, it strives to various parties to participate in all the means of social communication and to take advantage of the relations between developers and consumers thanks to the organized communication and of high quality and speed sufficient on the internet.

\section{THE IMPACT OF THE ANNOUNCEMENT IN THE SOCIAL NETWORKS}

Customer value is usually defined as the expected profit from sales to that customer, over the lifetime of the relationship between the customer and the company (Domingos P (2005). Customer value is of critical interest to companies, because it determines how much it is worth spending to acquire a particular customer. The first, it is important that the customer like the product, preferably a lot. The second, if influence is symmetric, there is no advantage in searching for the most influential customers.

The third and perhaps most important aspect is that a customer's network value does not end with her immediate acquaintances. Those acquaintances in turn influence other people, and so on recursively until potentially the entire network is reached. In viral marketing, giving a product free to a well-chosen customer could pay off many times in sales to other customers.

The advertisement on the sites of social communication represents the modern technique to attract the attention of the reader, in particular in the field of its competence or of its wishes that they are looking for. The impact of content of announcement in these sites has a positive impact, particularly for the target category of a trademark. In addition, they contribute advertising campaigns, rapid promotion and positive about the various electronic products, especially which are of a technical nature, which can be downloaded such as software, magazines and newspapers, electronic books, applications and other. Fig. 2 .

Here is the process of communication between the seller and the buyer and therefore it can divide these relations with the customer in five steps:

\section{A. The Customer (Receives the Advertising Messages)}

The social network has changed the mode of communication with clients and to take the decisions of purchase. It has transformed these channels to continue permanently on the developments at the local level and in the world and the client has become receive millions of advertising messages by electronic advertising.

As the customer is also becoming informed in particular to what are published products and services, even and had not participated by the comment and the intervention, he became, in place of the spectator or of the recipient of these announcements electronically.

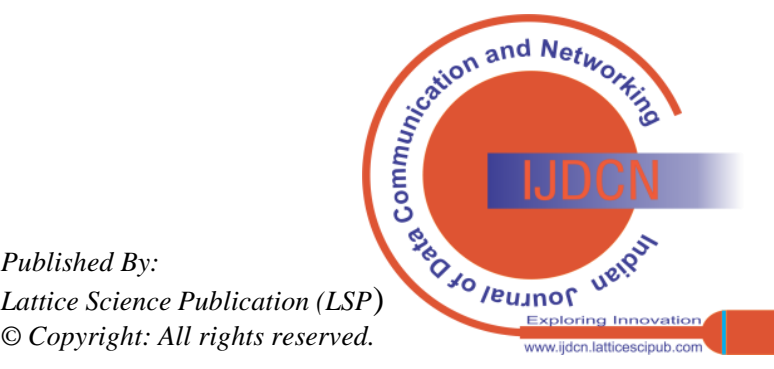


The receipt of these announcements by a large part of the community who use social networking sites to a considerable impact on the trends in the consumption of brand or product which would be desirable to insist on the credibility of the advertising content and the source of the editor. However, if the recipient is losing the credibility as it contains information you will lose confidence in the company.

What affect of negative way to the request and the consumer makes the search for companies or of replacement products or lack of interest in the electronic advertisement which is published on the pages of social communication. A retail bank has more than a million customers, but most utilize only one or two of the banks services (Knott A, Hayes A and Neslin S.A (2002)) [14]. The banks wants to increase us age of its full product line. A software company knows which of its customers have bought which of its products. It wants to know which additional selections it should target to which customers. Liedtka J (2014) [17]. witnessed the positive impact when teams were able to identify and focus attention on what really mattered to the people for whom they were trying to create value. Agreement on what really mattered these customers allowed teams to cut through the clutter, confusion and information overload to achieve focus.

\section{B. The Customer (Gives Its Opinion And Comment on the Announcement)}

For a popular product, the number of reviews can be in hundreds (Hu M and Liu B (2004)) [10]. This makes it difficult for a potential customer to read them in order to make on whether to buy the product. In order to enhance customer satisfaction and their shopping experiences, it has become a common practice for online merchants to enable their customers to review or to express opinions on the products that they buy. Hu M and Liu B (2004) [10]. are only interested in features of the product that customers have opinions on and whether the opinions are positive or negative. The objective is to produce a feature-based summary of large number of customer reviews of a product sold online. This theory believes that this problem will become increasingly important as more people are buying and expressing their opinions on the web. In addition, people can be interviewed individually or in groups (Keeney R.L (1999)) [13]. At the beginning, clarify that the purpose is to understand all the possible pros and cons of internet purchases versus purchases by other means or not purchasing a product. Keeney R.L (1999) [13]. determines the overall fundamental objective is to maximize customer satisfaction. Its component fundamental objectives collectively can be used to describe the complete value proposition of an internet purchase to a prospective customer. The consumers' new media activities can be seen by others (Hennig-Thuran T, Malthouse F.C, Friege C, Gensler S, Lobschat L, Rangaswamy A and Skiera B (2010)). Entries made by a consumer in forums, blogs, and social communities can be tracked by other consumers as well as companies. In this reason, that score high on both kinds of attitudes will exhibit high new media brand engagement-non-purchase customer behaviors that involve new media, such as creating and watching Youtube videos about the brand, blogs, web sites, reviews, etc. Before the launch of a campaign of electronic advertising on the means of social communication ensures that it must take into consideration the age group, sex, country, the quality of the products, the target groups and interested prairie products.
Consequently, the campaigns have achieved its objectives from to respond to the needs and desires of consumers on the means of social communication. The client is always seeking the assistance to achieve the best decisions to purchase with the participation of conversation in two directions. Also you can involve many customers to their campaign by click and to observe and comment on the electronic ads. The target client has become a partner in the promotion and a privileged consumer about the quality of certain electronic products. This contributes to the ongoing dialogue on the pages of social communication for the products and services of electronic companies to strengthen trust between the two parties through to hear the comments, the additives and the criticisms or proposals. By following the subscriber in page to a total freedom in the interaction and to pronounce and comment on the announcement on what has published the proponent or the society.

\section{The Customer (Convinced by the Company or the Proponent)}

Nambisan S (2002) [19]. focuses on technology-based virtual environments that offer new avenues for firms to enhance their social capital opposite their relationships with customers and to facilitate value creation. The customers also play a valuable role as co creators of new products, in which their participation ranges from product design activities to product development activities.

The customer as user, as primary recipients and users of goods and services, customers can create two valuable outcomes-in product testing and in product support. The role of customers in testing new products is not new. The creation of a social campaign requires integrating a largest possible number of the means of social communication and connecting tracks to continue directly with clients from the discussions and comments. One of the main advantages of marketing through the networks of social communication we find the most important component, it is the confidence to the source and the product prairies.

The process to convince the customer of the quality to contribute in a positive manner to gain the confidence and the request for purchase without hesitation. For example, if a client has entered a page of social communication specific and has found many comments saying that this product of high quality and therefore the customer will be positively affected by these comments and to convince them of the company or of the products the prairies. If the comments indicate that the product is bad the confidence here would not be more exist and do not fall within the operation of purchase and therefore the corporation loses many customers.

The study of Hossain M.S and Rahman M.F (2017) [9], confirm the price is the amount of money that customer wants to pay for getting the product. Online price includes the price information, payment method, payment process system, discount, offers and details of credit system. Company publishes a details list of price on website or sends mail to customer.

Customer can compare the price and quality of product through internet so online pricing strategy is more sensitive than traditional marketing.

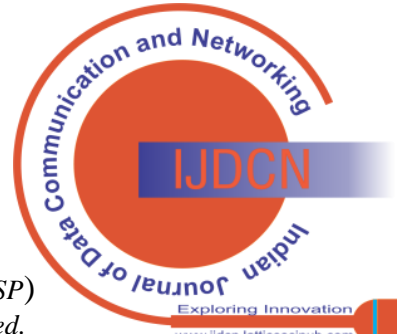




\section{The Customer (Discuss the Product)}

The media landscape on the means of social communication is large and attractive. This space is open to all and they can be your trade can flourish and higher rates of profit, if the process of controlling the advertising campaigns of way is satisfactory. The campaign of a trademark specific to you is an important element posed in the discussion with the client. The satisfaction in consumption or use can seldom be quite the same as earlier in trial or promise (Levitt T (1981) [16]. This study confirm that some promises promise more than others do, depending on product features, design, degree of tangibility, type of promotion, price, and differences in what customers hope to accomplish with what they buy. The management of relationships with customers through the hearing directly to their needs and the concentration of the improvement of the image or the morale of a product prairies has positively affected on the sale. Where before the purchase process is done the process to convince the client in direct connection with him through marketing campaigns and given him the most important characteristics and the quality and the price of the product on sale including the electronic markets.

\section{E. The Customer (Buy the Product)}

This is the last phase of promotion of products in consumption after persuading the quality of products intended for sale. In considering this process of phase to earn the confidence and strengthen the channels of social communication of the offer and the electronic application and update of the recovery and the delivery of the products to consumers. The study of Beneke J, Flynn R, Creig T and Mukaiwa M (2013) [3]. endeavours to examine the influence of perceived product quality, relative price and risk, respectively, on perceived product value and, ultimately, consumer's willingness to buy private label household cleaning products. This study also identified further relationships between the constructs, which influence perceived product value.

Before the management, certain campaign on the means of social communication it must concentrate on the maximum speed of communication on the internet that allows you to easily connect with customers and persuade them to the highest quality of your services and products. In addition, the content of the announcement of the advertisements of the company or sponsor has influenced directly to consumers and their behavior. This process is contributed to increase the part of the application of the products, in particular in the European countries, the United States, and the countries of the Gulf that is favored for this case of purchases with considerable demand. The process of the promotion of marketing of products through the steps starting to receive the electronic advertisement and the interaction with him and then the operation of the payment transaction and the purchase and then the transport of the product directly to consumers. By following all these steps to play an important role in the impact on the consumer and the success of the process of the promotion of electronic.

\section{CONCLUSION}

The networks of social communication today represent the last method of marketing for the promotion of electronic products in a modern way and the increase in sales and profits in the open market globally in the many targeted customers in the different world. First, it is necessary to use these means of so well of communication and publication and to attract visitors, in order to win the confidence of purchaser and the promotion of products in a way good and of high quality. Secondly, the techniques of communication on the web of the internet are considered to the main factor of the communication should therefore have an element of the maximum speed without interruption. Thirdly, the good control of the means of social communication audio and image and also with software for mobile phone which are considered the best ways to communicate with customers. In addition, the platforms of social communication represent a benefit and a financial source where it is located many of the electronic business transactions and financial. One can achieve considerable profits on a daily basis through the operations of the sale if the operation of these networks in a manner governed in the aim of promoting the greatest possible number of customers. The use of these modern techniques of marketing and management of the campaigns allow electronic companies and developers to contact with its customers very easily, and also to open the wide field to attract the largest possible number of interested parties of the products which are located in the promotion and also for the services of companies and promoters through the publication of images, video sequences, audio recordings, written announcements and visible and the commercial stores. It could undertake research and analysis on the networks of social communication include two types one free of charge by the publication and the promotion and the other by the assignment of a budget advanced in view of the management of the ads on these means. The modern techniques in the field of communication and social communicate, represent a source of huge wealth for the electronics companies and promoters if they are exploited by optimal methods because they represent a forum for millions of visitors and clients by day and can communicate with many of them to sell products given. Where through the marketing on the networks of social communication can influence to attract the attention of the reader through the publication of advertisements to electronic a given mark. Thereafter opens the field to the clients to receive advertising messages, pronounce his opinion and comments on the announcement and the confidence of the society or promoter, to discuss product and to buy this product. In general, thanks to these modern techniques of exploitation of platforms of social communication with customers and the management of marketing campaigns on these means with methods governed and organized could impact on consumers of the content of a brand commercial advertising prairie and this by the direct interaction with customers to make known their views and their comments, their interests, their desires and the discussion and activate the process of buying the product. The Gain of the confidence of customers with the means of social communication has made huge profits to the company's and to proponents. electronic 
Accordance with the surveys of the largest corporations in global electronic commerce, the means of social communication become a financial source of mass electronic work to achieve a considerable wealth and a great evidence of it in the wealth of the new world is that can the promotion on the networks of social communication.

\section{REFERENCES}

1. M. Bampo, M.T. Ewing, D.R. Mather, D. Stewart, and M. Wallace, (2008), " The effects of the social structure of digital networks on viral marketing performance ", Information Systems Research, Vol.19, N³, pp.273-290. [CrossRef]

2. S. Bellman, R.F. Potter, S. Treleaven-Hassard, J.A. Robinson, and D. Varan, (2011), " The effectiveness of branded mobile phone apps », Journal of Interactive Marketing, Vol.25, pp.191-200. [CrossRef]

3. J. Beneke, R. Flynn, T. Greig, and M. Mukaiwa, (2013), « The influence of perceived product quality, relative price and risk on customer value and willigness to buy: a study of private label merchandise ", Journal of product \& Brand management, Vol.22, issue.3, pp.218-228. [CrossRef]

4. G. Blank, and C. Lutz, (2017), « Representativeness of social media in Great Britain : Investigating Facebook, LinkedIn, Twitter, Pinterest, Google+, and Instagram », American Behavioral Scientist, pp.1-16. [CrossRef

5. Lo Y. Chen, and Fang, C.Y. (2017), « Facebook marketingcampaign benchmarking for a franchised hotel », International Journal of Comtemporary Hospitality Management, pp.1-39.

6. P. Domingos, (2005), « Mining social networks for viral marketing », IEEE Intelligent Systems.

7. E. Griborn, and D. Nylén, (2017), « The role of Youtube in the digitalization of TV: A case study of novel value co-creation practices at United Screens ", Proceedings of the 50th Hawail International Conference on System Sciences, pp.4786-4795. [CrossRef]

8. T. Hennig-Thurau, E.C. Malthouse, C. Friege, S. Gensler, L. Lobschat, A. Rangaswamy, and B. Skiera, (2010), « The impact of new media on customer relationships », Journal of Service Research, Vol.13, N³, pp.311-330. [CrossRef]

9. M.S. Hossain, and Rahman, M.F. (2017), "Tools of online marketing », International Journal of Science and Business, Vol.1, Issue.1, pp.1-7.

10. M. Hu, and B. Liu, (2004), « Mining opinion features in customer reviews », American Association for Artificial Intelligence, pp.755-760.

11. B.J. Jansen, and M. Zhang, (2009), « Twitter Power: Tweets as Economic word of mouth ", Journal of the American Society for Information Science and Technology, Vol.60, $\mathrm{N}^{\circ} 11$, pp.2169-2188. [CrossRef]

12. T Janusz,. (2009), «Marketing on Social Networks: Twitter, MySpace and Facebook Demystified », Marketing on Social Networks, Vol.17, N4, pp.124-125.

13. R.L. Keeney, (1999), "The value of internet commerce to the customer », Management Science, Vol.45, N4, pp.533-542. [CrossRef]

14. A. Knott, A. Hayes, and S.A. Neslin, (2002), « Next product to buy models for cross selling applications », Journal of Interactive Marketing, Vol.16, $\mathrm{N}^{\circ} 3$, pp.59-75.]

15. W. Lassar, B. Mittal, and A. Sharma, (1995), « Measuring customer-based brand equity ", Journal of Consumer Marketing, Vol.12, Issue.4, pp.11-19. [CrossRef]

16. T. Levitt, (1981), « Marketing Intangible Products and Product Intangibles », The Cornell H.R.A Quarterly, pp.37-44. [CrossRef]

17. J. Liedtka, (2014), «Innovative ways companies are using design thinking ", Strategy \& Leadership, Vol.42, N², pp.40-45. [CrossRef]

18. M.B. McCabe, (2017), « Social media marketing strategies for career advancement : An analysis of LinkedIn », Journal of Business and Behavioral Sciences, Vol.29, N¹, pp.85-99.

19. S. Nambisan, (2002), « Designing virtual customer environments for new product development: Toward a theory ", Academy of Management Review, Vol.27, N³, pp.392-413. [CrossRef]
20. F. Sabbagh, (2017), «The campaigns on the means of social communication », Edition Knoowy, Study Documents.

21. M. Saravanakumar, and T. Sugantha Lakshmi, (2012), « Social media marketing », Life Science Journal, Vol.9, N4, pp.4444-4451.

22. A. Scharl, A, Dickinger. and J, Murphy. (2005), « Diffusion and success factors of mobile marketing ", Electronic Commerce Research and Applications, Vol.4, pp.159-173. [CrossRef]

23. A.N. Smith, E. Fischer, and C Yongjian, (2012), «How Does Brand-related user-generated content differ across Youtube, Facebook, and Twitter ? ", Journal of Interactive Marketing, Vol.26, pp.102-113. [CrossRef]

24. N. Steino, and M.S. Khalid, (2017), « The hybrid studio introducing Google+ as a blended learning platform for architectural design studio teaching », Journal of problem based learning, Vol.5, N¹, pp.22-46.

\section{AUTHORS PROFILE}



Foued Sabbagh, Masters Degree in economics sciences specialty Finance and Development in 2010 from the Faculty of Law and Economics and Political Sciences of Sousse - University of Sousse Tunisia and International Economic Researcher, fouedsabbagh_2010@yahoo.fr https://www.academia.edu/FouedSabbagh

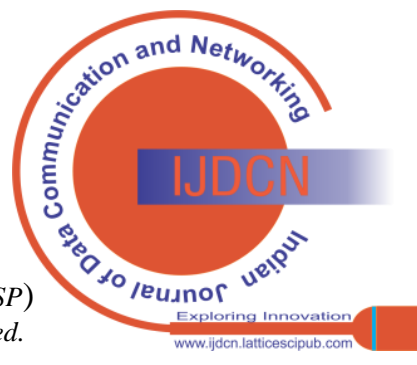




\section{ANNEXES}

FIG.1. THE MOST IMPORTANT NETWORKS OF SOCIAL COMMUNICATION

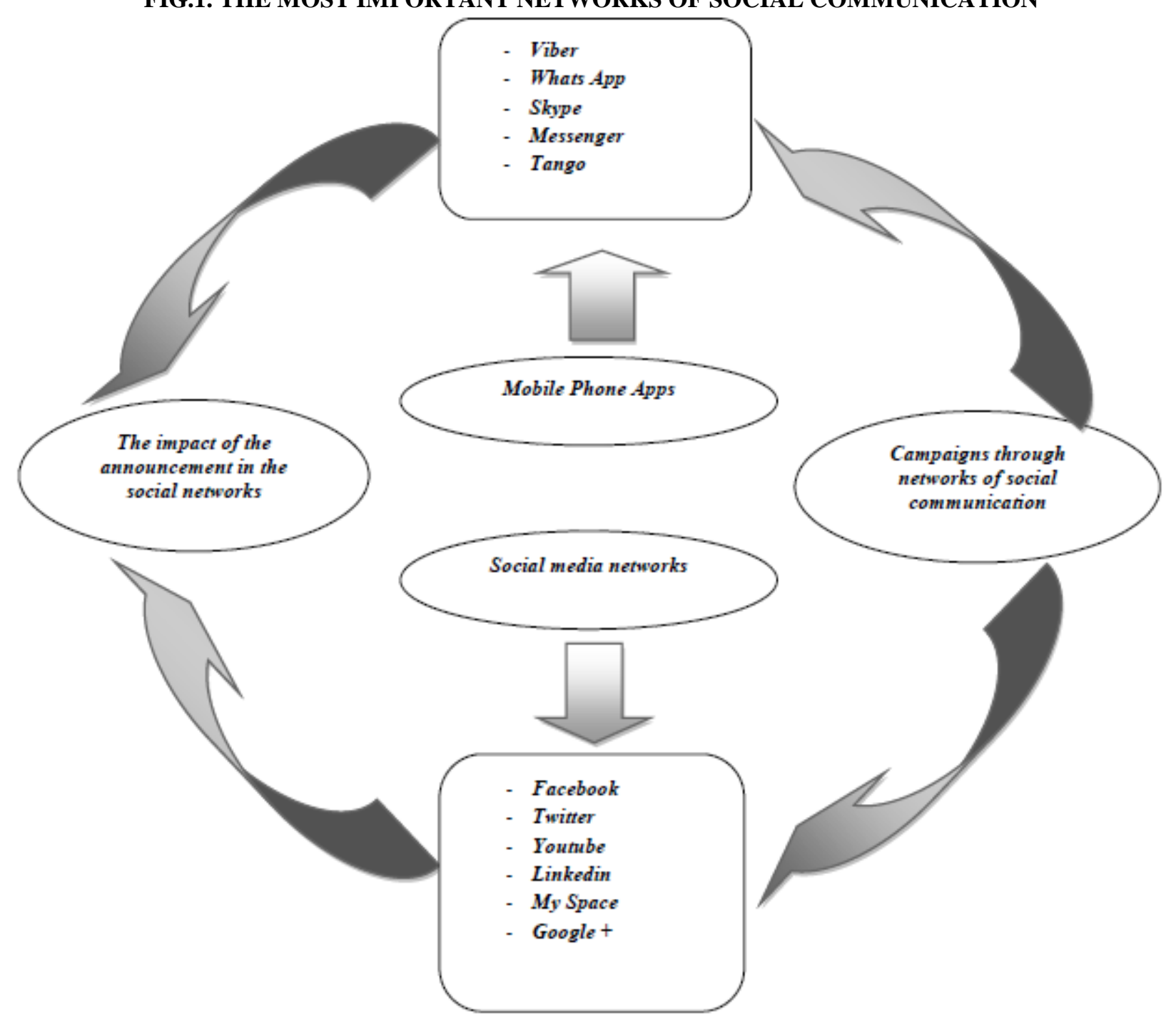

Source: Foued Sabbagh (2017) [20]

FIG.2. THE IMPACT OF THE ANNOUNCEMENT IN THE SOCIAL NETWORKS

The announcement in the social networks

\begin{tabular}{|c|c|c|c|c|}
\hline $\begin{array}{c}\text { The customer } \\
\text { (Receives the } \\
\text { advertising } \\
\text { messages) }\end{array}$ & $\begin{array}{c}\text { The customer } \\
\text { (Gives its opinion } \\
\text { and comment on } \\
\text { the } \\
\text { announcement) }\end{array}$ & $\begin{array}{c}\text { The customer } \\
\text { (Convinced by } \\
\text { the company or } \\
\text { the proponent) }\end{array}$ & $\begin{array}{c}\text { The customer } \\
\text { (Discuss the } \\
\text { product) }\end{array}$ & $\begin{array}{c}\text { The } \\
\text { customer } \\
\text { (buy the } \\
\text { product) }\end{array}$
\end{tabular}

Source: Foued Sabbagh (2017)

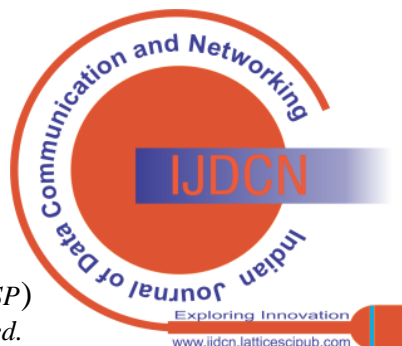

